\title{
RESUME PERJUANGAN DIPLOMASI INDONESIA
}

\author{
NAMA : HASTUTI \\ NIM : 90100121067 \\ KELAS : EKIS.C
}

\section{A. Perjanjian Linggarjati}

Perjanjian Linggarjati merupakan Perjanjian yang muncul setelah Belanda melakukan serangan pasca diumumkan kemerdekaan Indonesia 17 Agustus 1945. Belanda yang tidak mengakui kemerdekaan Indonesia berusaha untuk merebut dan menegakkan wilayah kekuasaan di Indonesia. Permasalahan yang diangkat dalam penelitian ini yaitu untuk menguraikan Perjanjian Linggarjati. Tujuan penelitian ini adalah untuk mengetahui bentuk perjuangan bangsa Indonesia melalui Perjanjian Linggarjati. Metode penelitian yang digunakan dalam penelitian ini adalah metode sejarah yang terdiri dari tahapan heuristik, kritik sumber, interpretasi, dan historiografi. Hasil penelitian menunjukkan bahwaalam perjanjian Linggarjati, wilayah Indonesia yang diakui oleh Belanda meliputi Jawa, Sumatera, dan Madura. Belanda juga membentuk negara boneka untuk mempersempit ruang gerak Republik Indonesia. Kesimpulannya, yaitu: Perjanjian Linggarjati membuat wilayah kekuasaan Republik Indonesia semakin sempit yang hanya sebatas Jawa, Sumatera, dan Madura. Untuk mempersempit ruang gerak Republik Indonesia, Belanda membentuk negara boneka. Perjanjian Linggarjati diakhiri dengan perjuangan bangsa Indonesian dalam merebut kemerdekaan secara de facto dan de jure atas seluruh wilayah Republik Indonesia yang dikuasai Belanda.

Pada akhir Agustus 1946, pemerintah Inggris mengirim Lord Killearn ke Indonesia dalam misi menyelesaikan perundingan antara Indonesia dengan Belanda. Lalu pada tanggal 7 Oktober 1946 di Konsulat Jenderal Inggris di Jakarta, dibuka perundingan antara Indonesia dan Belanda. Dalam perundingan tersebut akhirnya menghasilkan persetujuan gencatan senjata pada 14 Oktober. Kemudian dilanjutkan dengan Perundingan Linggarjati yang terjadi pada tanggal 11 November 1946. Perundingan ini dipimpin oleh wakil Inggris bernama Lord Killearn. Pihak Indonesia diwakili oleh Perdana Menteri Sultan syair, Muh. Rum. Susanto Tirtropojo dan dr. A.K. Gani. Sutan Syahrir sebagai ketuanya. Sementara delegasi Belanda diketuai oleh Dr. H.J. Van Mook. Tokoh-tokoh Indonesia itulah yang menandatangani Perjanjian Linggarjati. Sedang dari Belanda yang menandatangani ialah Prof. Schermerhorn, Dr. H.J. Van Mook dan Van Poll Sutan Syahrir memilih Linggarjati, sebagai tempat pertemuan bersejarah itu. Perjanjian Linggarjati selesai pada tanggal 15 November 1946 dan baru ditandatangani keduanya pada 25 Maret 1947.

Isi Perjanjian Linggarjati 
Perjanjian Linggarjati yang ditandatangani pada tanggal 25 Maret 1947 tersebut menghasilkan beberapa poin dan pasal, yaitu:

1. Belanda mengakui secara de facto wilayah Republik Indonesia, meliputi Jawa, Sumatera, dan Madura

2. Belanda harus meninggalkan wilayah Republik Indonesia selambat-lambatnya pada tanggal 1 Januari 1949.

3. Belanda dan Indonesia sepakat untuk membentuk negara Republik Indonesia Serikat (RIS).

4. RIS harus bergabung dengan negara-negara persemakmuran di bawah Kerajaan Belanda.

Adanya perjanjian Linggarjati tersebut tentunya memberikan dampak positif maupun negatif bagi Indonesia. Beberapa dampak positifnya, yaitu citra Indonesia di mata dunia semakin kuat, dengan adanya pengakuan Belanda terhadap kemerdekaan Indonesia.

\section{B. Agresi Militer I}

- Pada tanggal 21/7/1947 Belanda menyerang Indonesia. Menguasai seluruh pelabuhan di Jawa. Penangkapan orang China di Jawa Barat bangsawan di Sumatera di bunuh.

- Pada tanggal 29/8/1947 Belanda deklarasikan garis demarkasi Van Mook yang membuat wilayah Indonesia lebih sedikit.

- Pada tanggal 18/9/1947 Komisi 3 negara di bentuk untuk menyelesaikan masalah.

Sebab Agresi Militer Belanda I adalah kekalahan Belanda dalam peperangan.Kekalahan itu membuat ekonomi Belanda lesu. Belanda pun ingin membangkitkan perekonomian negaranya dengan kembali menguasai kekayaan alam Indonesia. Sejumlah tentara Belanda pun dikirim kembali ke Indonesia. Belanda datang dengan membonceng pasukan sekutu yang menang Perang Dunia II. Kali ini, Belanda datang dengan bendera baru. Bukan lah VOC, melainkan NICA (Netherlands Indies Civiele Administration) atau Pemerintahan Sipil Hindia Belanda. NICA mendarat di Sabang, Aceh dan sampai di Jakarta pada 15 September 1945. Tentara NICA dipimpin oleh Letnan Gubernur Jenderal Hubertus van Mook.

Agresi Militer Belanda I memiliki tujuan menguasai sumber daya alam Indonesia yang berada di Sumatera dan Jawa. Di pulau Jawa, Belanda bergerak ke Jawa Barat, Jawa Tengah, dan Jawa Timur. Mereka hendak menguasai perkebunan, pabrik, dan pelabuhan. Sementara di Sumatera, Belanda bertujuan menguasai perkebunan dan pertambangan khususnya minyak dan batu bara. Kekayaan alam ini akan menjadi modal ekonomi Kerajaan Belanda. Belanda melancarkan serangan yang menyebabkan banyak orang meninggal dunia.

Pemerintah Indonesia melaporkan agresi militer ini kepada Perserikatan BangsaBangsa (PBB). PBB lantas mengeluarkan resolusi pada 1 Agustus 1947. Dewan Keamanan PBB terus mendesak Belanda menghentikan agresi militer. Belanda pun menerima resolusi itu dan menyetop pertempuran pada 5 Agustus 1947. 


\section{Agresi Militer Belanda II}

Dalam Agresi Militer Belanda II, pasukan militer Belanda awalnya menyerang Pangkalan Udara Maguwo agar bisa masuk ke Yogyakarta. Belanda menggempur pangkalan udara itu secara tiba-tiba melalui serangan udara. Setelah Pangkalan Udara Maguwo lumpuh,Belanda dengan cepat menguasai Yogyakarta. Pemimpin Indonesia saat itu, Presiden Soekarno dan Wakil Presiden Mohammad Hatta ditangkap. Belanda juga menangkap sejumlah tokoh seperti Sutan Sjahrir, Agus Salim, Mohammad Roem, dan AG Pringgodigdo. Mereka diterbangkan ke tempat pengasingan di Pulau Sumatera dan Pulau Bangka.Pembentukan Pemerintahan bukit tinggi setelah gagal dengan agresi militer yang pertama pada 21 Juli - 5 Agustus 1947, Belanda kembali menyerang Indonesia setahun kemudian.

Agresi Militer Belanda II adalah serangan yang dilancarkan Belanda pada 19-20 Desember 1948. Operasi Gagak ini berawal dari serangan di Yogyakarta yang saat itu merupakan ibu kota dan pusat pemerintahan Indonesia. Serangan pun meluas ke sejumlah kota di Jawa dan Sumatera. Tujuan Agresi Militer Belanda II adalah untuk melumpuhkan pusat pemerintahan Indonesia sehingga Belanda bisa menguasai Indonesia kembali. Belanda ingin merebut kekayaan alam yang ada di Indonesia untuk menumbuhkan perekonomian negaranya yang hancur setelah kalah dalam Perang Dunia II. Sebelum ditangkap, Presiden Soekarno sempat membuat surat kuasa kepada Menteri Kemakmuran Syafruddin Prawiranegara untuk membuat pemerintahan darurat sementara. Soekarno memberikan mandat kepada Syafruddin untuk membentuk Pemerintahan Darurat Republik Indonesia (PDRI) di Bukittinggi, Sumatera Barat. Peralihan pemerintahan ini bertujuan agar Republik Indonesia tidak berhenti dan terus menyusun strategi melawan Belanda.Presiden Soekarno juga sudah membuat rencana cadangan seandainya Pemerintahan Darurat ini gagal menjalankan tugas pemerintahan.Soekarno membuat surat kepada Duta Besar RI di New Delhi, India, Sudarsono,Menteri Keuangan AA Maramis dan staf Kedutaan RI LN Palar untuk membentuk Exile Government of Republic Indonesia di New Delhi, India. Exile Government adalah pemerintah resmi suatu negara yang karena alasan tertentu tidak dapat menggunakan kekuatan legalnya.

Namun, rencana ini tak jadi dilakukan karena PDRI berhasil membentuk pemerintahan sementara pada 22 Desember 1948. Sejak saat itu, tokoh-tokoh PDRI menjadi incaran Belanda. Namun, PDRI tak gentar dan menyusun sejumlah perlawanan dengan membentuk lima wilayah pemerintahan militer di Sumatera yakni di Aceh, Tapanuli, Riau, Sumatera Barat, dan Sumatera Selatan. Perlawanan terhadap belanda juga dibantu berbagai laskar di Jawa. Serangan Belanda yang terus digencarkan justru mendapat kecaman dari dunia internasional. PBB mendesak Belanda membebaskan pemimpin Indonesia dan kembali memenuhi Perjanjian Renville.

\section{Persetujuan royem- royem (14/4/1949)}


Perjanjian Roem-Roijen atau Perjanjian Roem-Van Roijen merupakan suatu perjanjian antara Indonesia dengan Belanda yang dimulai pada tanggal 14 April 1949 dan akhirnya ditandatangani pada tanggal 7 Mei 1949 di Hotel Des Indes, Jakarta. Nama dari perjanjian ini diambil dari kedua pemimpin delegasi yaitu Mohammad Roem dan Herman van Roijen.

Maksud dari pertemuan ini adalah untuk menyelesaikan beberapa masalah mengenai kemerdekaan Indonesia sebelum Konferensi Meja Bundar di Den Haag pada tahun yang sama. Perjanjian tersebut berjalan sangat a lot sehingga memerlukan kehadiran Drs.Moh Hatta dari pengasingan di Bangka, dan juga Sri Sultan Hamengkubuwono IX dari Yogyakarta untuk mempertegas sikap dari Sri Sultan Hamengkubuwono IX terhadap Pemerintahan Republik Indonesia di Yogyakarta, di mana Sultan Hamengkubuwono IX mengatakan bahwa "Jogjakarta is de Republiek Indonesie" yang berarti "Yogyakarta adalah Republik Indonesia".

Adapun hasil dari perjanjian Roem-Roijen ini adalah sebagai berikut :

1. Angkatan bersenjata Indonesia akan menghentikan semua aktivitas gerilya.

2. Pemerintahan Republik Indonesia akan menghadiri Konferensi Meja Bundar.

3. Pemerintan Republik Indonesia dikembalikan ke Yogyakarta.

4. Angkatan bersenjata Belanda akan menghentikan semua operasi militer dan membebaskan semua tawanan perang.

Terdapat banyak sekali dampak yang ditimbulkan akibat adanya perjanjian Roem Royen pada keadaan di Indonesia. Isi perjanjian Roem Royen yang termasuk pembebasan tahanan politik sehingga Soekarno dan Hatta kembali ke Yogyakarta setelah diasingkan. Yogyakarta juga menjadi ibukota sementara dari Indonesia. Terjadi juga penyerahan mandat dari Sjafruddin Prawiranegara sebagai presiden PDRI (Pemerintahan Darurat Republik Indonesia) kembali kepada Ir. Soekarno. Yang paling terlihat yaitu dengan adanya gencatan senjata antara Belanda dan Indonesia. Perundingan Roem Royen ini pun pada akihrnya berujung dengan dilaksanakannya Konferensi Meja Bundar (KMB) di Den Haag, Belanda yang menghasilkan penyelesaian permasalahan antara Indonesia dan Belanda.

\section{E. Konverensi Meja Bundar (23/08/1949)}

Konferensi Meja Bundar (KMB) dilaksanakan pada tanggal 23 Agustus sampai 2 November 1949 di Den Haag (Belanda). KMB digelar setelah Belanda dan Indonesia melewati beberapa jalur diplomasi sebelumnya. Beberapa jalur diplomasi yang dilakukan oleh Belanda dan Indonesia diantaranya perundingan Linggarjati, perjanjian Renville, juga perjanjian Roem-Roijen. Dalam rangka mempercepat penyerahan kedaulatan, pemerintah Indonesia yang kala itu diasingkan di Bangka, bersedia mengikuti KMB. Pada tanggal 2 November 1949, persetujuan KMB berhasil ditandatangani.

Isi dari KMB adalah sebagai berikut. 
1. Masalah Irian Barat akan diadakan perundingan lagi dalam waktu 1 tahun setelah pengakuan kedaulatan RIS.

2. Antara RIS dan Kerajaan Belanda akan diadakan hubungan Uni Indonesia Belanda yang dikepalai Raja Belanda.

3. Kapal-kapal perang Belanda akan ditarik dari Indonesia dengan catatan beberapa korvet (kapal perang kecil) akan diserahkan kepada RIS.

4. Tentara Kerajaan Belanda selekas mungkin ditarik mundur, sedang Tentara Kerajaan Hindia Belanda (KNIL) akan dibubarkan dengan catatan bahwa para anggotanya yang diperlukan akan dimasukkan dalam kesatuan TNI.

Pada akhir Desember 1949, KMB mengeluarkan hasil yang menyatakan bahwa Indonesia diakui kedaulatannya oleh Belanda. Kemudian pada tanggal 27 Desember 1949, diadakanlah penandatanganan pengakuan kedaulatan di negeri Belanda. Pihak Belanda ditandatangani oleh Ratu Juliana, Perdana Menteri Dr. Willem Drees, Menteri Seberang Lautan Mr. AM . J.A Sassen. Sedangkan delegasi Indonesia dipimpin oleh Drs. Moh. Hatta. Pada waktu yang sama di Jakarta, Sri Sultan Hamengkubuwono IX dan Wakil Tertinggi Mahkota AH.J. Lovink menandatangani naskah pengakuan kedaulatan. Dengan diakuinya kedaulatan RI oleh Belanda ini maka Indonesia berubah bentuk negaranya berubah menjadi negara serikat yakni Republik Indonesia Serikat (RIS).Konferensi Meja Bundar tidak berjalan lancar.

Terdapat beberapa masalah yang terbilang sulit untuk dipecahkan. Nah diantaranya adalah:

1. Masalah istilah pengakuan kedaulatan dan penyerahan kedaulatan. Indonesia menghendaki penggunaan istilah pengakuan kedaulatan, sedangkan Belanda menghendaki istilah penyerahan kedaulatan.

2. Masalah Uni Indonesia-Belanda. Indonesia menginginkan agar sifatnya hanya kerjasama yang bebas tanpa adanya organisasi permanen. Sedangkan Belanda menginginkan kerjasama yang luas dengan organisasi yang luas pula.

3. Masalah hutang. Indonesia hanya mengakui hutang-hutang Hindia-Belanda sampai menyerahnya Belanda kepada Jepang. Sebaliknya Belanda berpendapat bahwa Indonesia harus mengambil alih semua kekayaan maupun hutang Hindia-Belanda sampai saat itu, termasuk biaya perang kolonial terhadap Indonesia. 